\title{
DAVID ROSENBERG UM NOME A SER REVERENCIADO
}

\author{
Tarcisio Triviño*
}

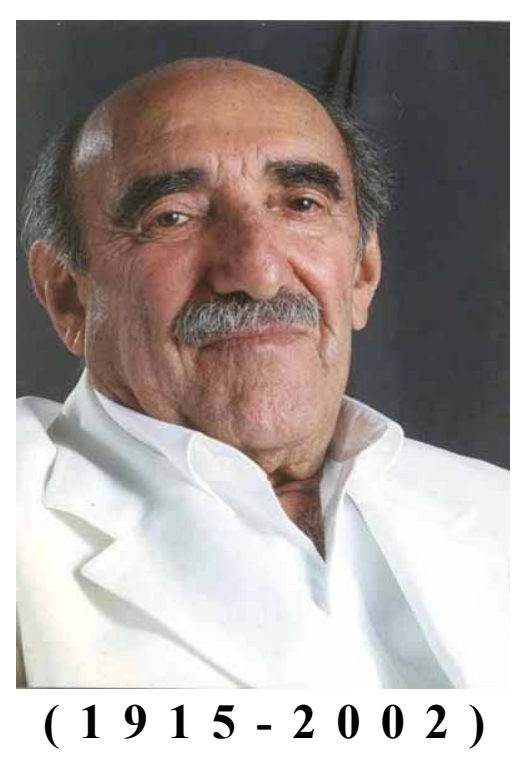

Não sou, seguramente, a pessoa mais qualificada para falar sobre o Prof. David Rosenberg. Isto porque fui um dos incontáveis cirurgiões privados do seu convívio por dezenas de anos. Apesar disso, o pouco tempo que com ele pude desfrutar foi suficiente para que sua personalidade deixasse em mim marcas tão profundas que me impediram de calar por ocasião de sua morte. Pouco sei sobre o início de sua carreira como cirurgião. Quando cheguei a Escola Paulista de Medicina, nos idos de 1967, ele já se encontrava afastado, dele restando apenas os ensinamentos sobre vagotomia, sutura em plano único, derivações venosas e tantos outros. Vítima de uma calúnia, arma poderosa dos covardes e incompetentes, fora afastado de suas atividades docentes pelo Governo Militar. Aqueles que injustamente queriam puní-lo, na verdade estavam privando os jovens médicos, particularmente os cirurgiões em formação na Escola Paulista, e, por conseqüência toda uma sociedade, da oportunidade de viver e aprender com uma das maiores personalidades da cirurgia brasileira. Diziam tratar-se de um cirurgião brilhante, mas, sobretudo, de um homem dotado de um entusiasmo contagiante, ávido por empreendimentos, sempre disposto a estimular os mais jovens. Não conheci o cirurgião, pois a idade nos ceifa, a todos, as habilidades técnicas tão indispensáveis à prática cirúrgica. Conheci o homem com entusiasmo contagiante, já próximo dos 80 anos, que, qual um jovem companheiro, tomou-me pelas mãos e me encaminhou para as minhas primeiras aventuras no exterior. Sabendo dos meus sonhos, dispôs-se, de imediato, a colaborar na sua concretização. Com telefonemas, cartas, pedidos, colocou-me, pela primeira vez, em 1992, em um serviço de referência em cirurgia

* Prof. Adjunto, Chefe da Disciplina de Gastroenterologia Cirúrgica do Departamento de Cirurgia da UNIFESP-EPM. Chefe do Setor de Transplante Hepático. Chefe do Grupo de Fígado e Vias Biliares. Vice-Chefe do Departamento de Cirurgia da UNIFESP-EPM. 
no exterior.A esta seguiram-se outras viagens, todas estimuladas, porque não dizer impulsionadas, pelo Prof. David. Devo a ele grande parte de minha formação cirúrgica, talvez a mais importante, e esta dívida de gratidão, já a ele manifestada em vida, não permitiu que eu silenciasse. Certamente numerosos outros cirurgiões também tiveram esta benção e devem estar fazendo coro com minhas palavras. Como docente da Disciplina de Gastrocirurgia também não poderia me omitir. Durante o pouco tempo que nossa Disciplina pôde desfrutar de sua companhia, particularmente nas visitas às enfermarias, aprendemos, nos sentimos estimulados e nos enriquecemos com sua cultura cirúrgica. Na busca de episódios que confirmassem estas afirmações, procurei, inicialmente na minha memória, e, posteriormente nos arquivos do Hospital São Paulo, um "caso clínico "que pudesse testemunhar a contribuição do Prof ${ }^{\circ}$ David Rosenberg. O documento encontrado revela os acontecimentos que se seguem.

Maria Sebastiana de Jesus, RG 738560, 57 anos, feminina, negra, solteira, do lar, natural de Minas Gerais e procedente de São Paulo.

Internada no Hospital São Paulo em $1^{\circ}$ de fevereiro de 1991, teve, após numerosos exames, os seguintes diagnósticos:

\section{$1^{0}$ Adenocarcinoma indiferenciado da papila duodenal.}

$2^{\circ}$ Colangite e provável abscesso hepático.

$3^{\circ}$ Volumoso mioma uterino.

\section{4- ${ }^{\circ}$ Hipertensão arterial.}

Como de costume o caso foi apresentado em visita do Grupo de Fígado, Vias Biliares e Pâncreas, em uma $3^{\mathrm{a}}$-feira, às 10:00 hs e, face aos diagnósticos, complicações e doenças associadas, foi contra-indicada a ressecção da neoplasia, e, portanto, o tratamento radical, optando-se por procedimentos paliativos. Como chefe do Grupo, após numerosos debates, concluímos como os demais, que a cirurgia radical envolvia riscos acentuados, resultados duvidosos e portanto contra-indicamos a gastroduodenopancreatectomia. Como sempre fazíamos, deixamos para o Prof. David Rosenberg os comentários finais, sempre acompanhados de citações, experiências e referências históricas. Desta vez o Prof. David foi enfático, discordando de todos e assumindo posição radical e mesmo heróica. Após consultar a doente voltou-se para nós e disse: "Esta mulher precisa e deseja ser operada. Tarcisio, mesmo sendo contrário a essa conduta, você vai operá-la, e da melhor maneira possível. Não negue a esta mulher a oportunidade que ela deseja. Tire primeiro o útero, para ampliar o campo operatório, depois faça a gastroduodenopancreatectomia".

Contrariando nossas posições, mas em respeito a decisão do Prof. David Rosenberg, operamos a Maria Sebastiana no dia 28 de fevereiro de 1991. Após histerectomia realizada pela equipe da Ginecologia procedemos a gastroduodenopancreatectomia, sem intercorrências porém com duração de 12:00 hs. No pós-operatório a doente apresentou acidente vascular cerebral isquêmico, que resultou em seqüela motora de pequena extensão. Recebeu alta hospitalar em 08 de abril de 1991 , no $34^{\circ}$ dia de pós-operatório. O exame anátomopatológico revelou adenocarcinoma papilífero bem diferenciado, margens cirúrgicas livres e ausência de comprometimento ganglionar. Seguiram-se numerosas consultas ambulatoriais, inicialmente a cada 6 meses e a seguir anualmente, sendo a última registrada nesta pasta, datada de 8 de janeiro de 2002, portanto, cerca de 11 anos após a indicação cirúrgica do Prof. David Rosenberg. Interrogada sobre sua qualidade de vida e suas atividades, respondeu: "Aos 70 anos tenho uma vida bastante satisfatória, que me permite cuidar de minha mãe, com mais de 90 anos, e que precisa muito de mim".

Não poderia haver uma evolução tão feliz para exemplificar e enaltecer a carreira do médico, cirurgião, professor e humanista David Rosenberg. Entendemos o quanto um homem como Prof. David é importante para uma Instituição como a nossa; reconhecemos o quanto foi prejudicial a sua ausência.

Aprendemos que homens como o Prof. David Rosenberg, presentes ou ausentes, devem ser eternamente reverenciados. 